\title{
EDITORIAL
}

\section{PSYCHOSOCIAL ASPECTS OF MILITARY COMMUNITIES}

Two papers published in this issue indicate the span of the involvement of psychiatry in the problems of the serviceman and of his family; one paper, 'First Aid for Prisoners of War' by Stephens (page 4) and a joint publication by Britton and Cordes (page 11). "A Comparison of Child Psychiatric Morbidity in American and British Military Families Overseas".

But wide interests in community problems are becoming increasingly relevant for many other medical disciplines, as knowledge grows about the role played by the environment, both physical and psychosocial, in the production of disease. As example, and of interest to military doctors is the current research in the American Navy by Rahe (1968) into a significant association between the immediate life pattern of servicemen and the onset of illness. The identification through history taking of morbidly vulnerable servicemen could be of very important predictive value in the selection of crews or teams for dispatch on missions or on expeditions involving long periods of isolation.

The traditional cast of the old Army Community, exercising paternalistic authority over its dependants, set in an Indian cantonment-like organisation with its rigidly guarded corporate life, has been undergoing a significant change, accelerated over the last decade. In a paper read to the United Services Section of the Royal Society of Medicine, Wawman (1967) attributed these changes to the new social pressures and attitudes burgeoning in the civilian community, and he described the ways in which the Army is adapting to them. Densham-Booth (1969) in a masterly social survey of three army garrison communities has revealed the extent and the momentum of this social change. He argues the case convincingly for a much improved social planning and for the provision of a variety of social and welfare services especially for young army families.

An awareness of such needs in military communities overseas led to the establishing of Child Guidance Clinics in B.A.O.R. and F.A.R.E.L.F., described elsewhere by Britton (1969); the first of these clinics was opened in 1965 by the Director-General of Army Medical Services. Since then there has been an encouraging growth in military communities of social workers and of other non medical members of the "helping professions ". Their numbers, however, are still far from adequate for dealing with the increasing psychosocial problems of modern military communities overseas. And, unfortunately, the country-wide shortage of social workers is likely to be aggravated, at least initially, by the implementation of the Seebohm report (1967). In this event the Army would be well advised to train its own social workers in uniform; perhaps one source might be the Army Nursing Service, to date so traditionally captive within its own hospital walls.

Since the Army is but an extension of the national society and particularly of its youth, we cannot validly assume that the current tides of its discontents with the adult world and its values will pass us by without creating troublesome turbulence in our own servicemen. Our relative freedom from the more disruptive, protesting or opting out phenomena prevalent in large sections of the national youth does not justify complacency, especially when we view developments in the armed forces of other countries. 
Rather it is our business as service medical officers to observe and to assess any turbulent or transgressive behaviour in young soldiers which is symptomatic of social frustration or discontent, and furthermore we should be prepared to offer our professional expertise towards preventative and management measures.

The general practitioner in the Army is probably more acutely aware than any of his medical colleagues of the increasing prevalance of psychosocial problems, since for him Problems rather than Sickness crowd his waiting room. This situation demands a closer and a more sophisticated collaboration between service doctors, commanders and staff officers and between them and the non medical members of the "helping" professions; the social workers, health visitors, S.S.A.F.A. welfare officers, youth officers, regimental family officers, housing managers and all the welfare agencies that are involved with service personnel.

Those of us who currently view medical training through Todd (1968) tinted spectacles recognise the prime importance of exposing medical officers and especially general practitioners during their general professional training to the socially loaded disciplines of psychiatry, paediatrics, army health and geriatric medicine. Doctors who seriously involve themselves with the community will eventually make the surprising but very rewarding discovery that they can harness their professional skills to the great therapeutic potential possessed by the community itself.

\section{REFERENCES}

Britton, R. (1969). “ An army child psychiatric clinic”. Proc. roy. Soc. Med. 62, 651.

Densham-BOOTH, D. F. (1969) "A sociological study of the human environment relating to soldiers' families". Unpublished study.

RAHE, R. (1968). " Life-change measurement as a predictor of illness ". Proc. roy. Soc. Med. 61, 1124-1126.

Report of Committee on Local Authority and Allied Personal Social Services (1967). H.M.S.O., London.

Report of Royal Commission on Medical Education (1968). H.M.S.O., London.

WAWMAN, R. J. (1967). “The changing military environment ". Proc. roy. Soc. Med. 61, 979-982.

\section{Representative Colonel Commandant}

Major-General T. M. A. Ahern, C.B.E., M.B., B.Ch., has been appointed Representative Colonel Commandant, Royal Army Medical Corps, for 1970.

\section{Polar Medal}

The Queen has been graciously pleased to approve the award of the Polar Medal to Major K. H. Hedges, R.A.M.C., member of the British Trans-Arctic Expedition 1968-1969. 